\title{
Meningkatkan Budaya Antri Anak Usia 4-5 Tahun melalui Metode Berbaris Sesuai Warna
}

\author{
Yeyen Sophiany Lau ${ }^{1 凶}$, Maria Melita Rahardjo² \\ Pendidikan Guru Pendidikan Anak Usia Dini, Universitas Kristen Satya Wacana \\ DOI: $10.31004 /$ obsesi.v5i1.624
}

\begin{abstract}
Abstrak
Kemampuan mengantri pada anak menjadi hal yang penting dalam perkembangan sosialemosional, namun pengamatan pendahuluan yang dilakukan oleh peneliti di TK Satria Tunas Bangsa menunjukkan bahwa masih banyak anak yang belum mampu mengantri. Penelitian ini bertujuan untuk meningkatkan budaya antri anak usia 4-5 tahun melalui metode berbaris sesuai warna di TK A Satria Tunas Bangsa. Penelitian ini termasuk jenis penelitian tindakan kelas. Teknik pengumpulan data dilakukan dengan observasi dan dokumentasi. Dari hasil analisis statistik deskriptif, penggunaan metode ini merupakan strategi pembelajaran yang efektif untuk meningkatkan budaya antri anak usia 4-5 tahun. Hal ini ditunjukan dari adanya peningkatan rata-rata persentase peningkatan antri dari pra siklus sampai siklus II yakni pada saat sebelum tindakan diperoleh hasil $75 \%$ saat masuk kelas dan $75 \%$ saat cuci tangan, siklus I $73 \%$ saat masuk kelas dan $81 \%$ saat cuci tangan, dan siklus II mencapai 96\% saat masuk kelas dan 90\% saat cuci tangan. Metode "berbaris sesuai warna" adalah salah satu strategi pembelajaran yang sesuai dengan prinsip pembelajaran pada anak usia dini, yaitu bermain sambil belajar.
\end{abstract}

Kata Kunci: budaya mengantri; metode berbaris sesuai warna.

\begin{abstract}
The ability to queue-up in children is important in socio-emotional development, however preliminary observations made by researchers at the Satria Tunas Bangsa Kindergarten showed that there were still many children who have not been able to queue. This study aims to improve the culture of queuing-up in children aged 4-5 years through the method of liningup according to color in TK A Satria Tunas Bangsa. This research is classroom action research. Data collection techniques were done by observation and documentation. From the results of descriptive statistical analysis, the use of this method is an effective learning strategy to improve queuing culture of children aged 4-5 years. This is shown from the increase in the average percentage increase in the queue from pre cycle to cycle II, which is $75 \%$ when entering the class before the action and $75 \%$ when washing hands, $73 \%$ when entering the class and $81 \%$ when washing hands, and cycle II reaches $96 \%$ when entering class and $90 \%$ when washing hands. The method of "lining-up according to color" is one of the learning strategies that is in accordance with the principles of learning in early childhood, which is to play while learning.
\end{abstract}

Keywords: queuing culture; method of lining-up according to color.

Copyright (c) 2020 Yeyen Sophiany Lau, Maria Melita Rahardjo

$\square$ Corresponding author :

Email Address : maria.melita@uksw.edu (Jln. Diponegoro No. 52-60, Salatiga, Jawa Tengah)

Received 29 June 2020, Accepted 3 August 2020, Published 20 August 2020 


\section{PENDAHULUAN}

Perkembangan sosial adalah tingkat jalinan interaksi anak dengan orang lain, mulai dari orang tua, saudara, teman bermain, hingga masyarakat secara luas sedangkan perkembangan emosional adalah luapan perasaan ketika anak berinteraksi dalam kehidupan sehari-hari (Diana, 2010). Salah satu aspek perkembangan sosial-emosional yang penting sebagai penentu kualitas hidup anak di masa depan adalah regulasi diri atau self regulation. Salah satu cara anak melatih regulasi dirinya adalah melalui mengantri (Zubaida, 2016).

Lingkungan sekitar sangatlah berpengaruh dalam mendukung kebiasaan antri pada anak. Salah satu cara untuk mengajarkan antri pada anak adalah melalui pembiasaan sejak dini dan dimulai secara konsisten di lingkungan keluarga maupun lingkungan sekolah. Dampak positif dari kebiasaan antri/ menunggu giliran bagi perkembangan anak antara lain yakni meningkatkan disiplin. Selain itu menerapkan budaya antri dapat memberikan hal positif yaitu belajar untuk bersabar dalam hal menunggu dan belajar akan hal rasa malu untuk menyerobot (Mann, 1969).

Regulasi diri merupakan seperangkat kemampuan untuk membantu memanfaatkan keterampilan yang tepat, mengelola respon kita terhadap dunia dan menolak tanggapan yang tak pantas (M. M. McClelland, Wanless, \& Lewis, 2016). Selain itu regulasi diri juga mengacu pada beberapa proses rumit yang memungkinkan anak-anak untuk merespon lingkungan mereka dengan tepat. Regulasi diri bukan keterampilan yang mengisolasi. Anakanak harus memahami apa yang mereka alami dan menjadikan sebagai informasi yang dapat digunakan untuk mengatur pikiran, emosi dan perilaku mereka (Megan M. McClelland \& Tominey, 2018).

Perkembangan anak sangat penting karena merupakan masa perkembangan yang sangat pesat dan fundamental bagi kehidupan selanjutnya. Berbagai tes menunjukkan bahwa anak mulai berkembang tak lama setelah lahir. Pertumbuhan ini berlanjut sepanjang masa kanak-kanak, dengan percepatan perkembangan lainnya pada akhir masa remaja dan dewasa awal. Pengendalian diri terbuka lebar pada saat anak memasuki usia 3-5 tahun. Artinya, usia tersebut adalah usia dimana anak dapat mengembangkan dan mempelajari regulasi diri dengan sangat optimal.

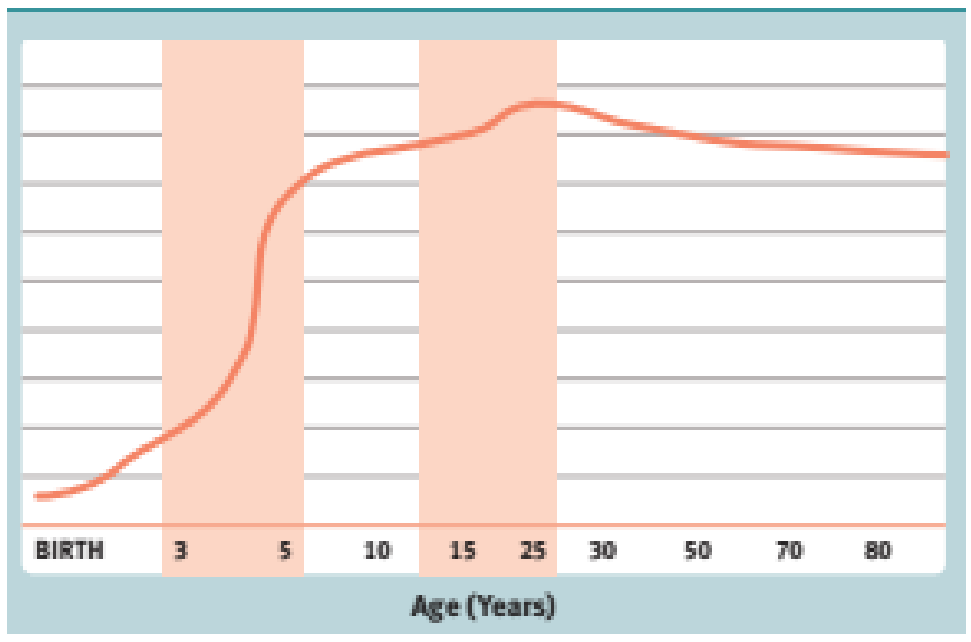

Gambar 1. Grafik Percepatan Perkembangan

Dari Gambar 1 menjelaskan tentang grafik perkembangan anak yang mulai berkembang tak lama setelah lahir dengan percepatan perkembangan di usia 3-5 tahun. Perkembangan ini berlanjut sepanjang masa kanak-kanak dengan percepatan lain pada akhir masa remaja dan dewasa diikuti oleh penurunan bertahap di kehidupan selanjutnya (Mukti, 2014). 
DOI: $10.31004 /$ obsesi.v5i1.624

Beberapa hasil penelitian sebelumnya seperti yang dilakukan menunjukkan bahwa pembiasaan antri dapat meningkatkan disiplin anak. Metode yang digunakan agar pembiasaan antri dapat berjalan efektif melalui pemberian motivasi kepada peserta didik agar mau ikut mengantri yaitu dengan memberikan pengertian kepada peserta didik dengan gambar-gambar yang menarik tentang guna dan manfaat antri dengan cerita dan dengan melakukan kegiatan antri tersebut secara terus menerus dan konsisten sehingga menjadi kebiasaan (Umayah, 2016).

Penelitian lain dilakukan oleh tentang meningkatkan kedisiplinan dalam budaya antri anak usia 3-4 tahun melalui kegiatan fun game menunjukkan bahwa kegiatan fun game dapat meningkatkan sosial emosional (pengembangan karakter) dalam hal kedisiplinan pada budaya antri anak. Selain penelitian ilmiah, banyak pula metode kreatif yang dibagikan di artikel populer maupun video youtube untuk melatih anak mengembangkan kemampuan antrinya. Berbagai metode tersebut antara lain adalah gerak berbaris.

Berbagai cara yang dapat digunakan untuk mengembangkan kemampuan mengantri pada anak usia dini (AUD) antara lain dengan kegiatan fun game yang dapat meningkatkan disiplin anak dalam hal mengantri (Hakim \& Kumala, 2016) Selain itu ada beberapa cara lain yaitu dengan merencanakan sesuatu yang harus dilakukan sambil menunggu seperti: mengambil mainan, menyikat gigi, dan lain sebagainya. Membantu anak bermain dengan mainan yang berbeda tetapi memiliki daya tarik yang sama sambil menunggu mainan yang diinginkan apat membantu anak mengetahui cara menunggu giliran secara baik (Musfiroh, 2012).

Berdasar kajian di atas, kemampuan mengantri pada anak menjadi hal yang penting untuk dikembangkan. Namun kenyataanya, pengamatan pendahuluan yang dilakukan oleh peneliti di KB/ TK STB menunjukkan bahwa masih banyak anak yang belum mampu mengantri. Mereka saling mendorong saat ingin mencuci tangan sehingga akhirnya ada anak lain yang menangis. Pada saat masuk kelas beberapa anak tidak mau mengantri. Mereka ingin jadi pertama tanpa melihat bahwa sudah ada teman mereka yang terlebih dahulu berbaris. Selain itu anak tidak mau menunggu giliran saat ingin bertanya.

Penelitian-penelitian terdahulu telah dilakukan berkaitan dengan disiplin mengantri dan perkembangan sosial-emosial pada anak seperti yang dilakukan (Harliana, 2019; Hodijah, Rachmawati, \& Agustin, 2019). Namun, belum secara gamblang mengutarakan metode-metode aplikatif yang dapat diterapkan secara langsung di kelas. Dengan adanya permasalahan-permasalahan di atas, penulis tertarik menggunakan salah satu metode untuk meningkatkan pembiasaan antri anak melalui metode "berbaris sesuai warna". Metode ini merupakan salah satu alternatif dalam metode pelaksanaan pembelajaraan yang diduga dapat meningkatkan pembiasaan antri pada anak usia dini (AUD). Oleh karena itu, penelitian ini bertujuan untuk meningkatkan kemampuan antri pada anak usia 4-5 di KB/TK STB melalui metode Berbaris Sesuai Warna .

\section{METODOLOGI}

Penelitian ini dilaksanakan di TK Satria Tunas Bangsa, Salatiga. Subyek dalam penelitian ini adalah peserta didik yang berjumlah 18 anak, TK A kelompok 1 usia 4-5 tahun. Penelitian ini menggunakan Penelitian Tindakan Kelas (PTK) yang hasilnya akan dipaparkan secara deskriptif. Pada penelitian tindakan kelas ini digunakan analisis berdasarkan hasil observasi kegiatan pembelajaran maupun dari hasil tindakan yang telah dilakukan. Analisis data deskriptif statistik dari hasil observasi terhadap guru sebagai pelaksana kegiatan pembelajaran digunakan untuk melakukan refleksi, agar peneliti dapat menentukan tindakan yang dapat diambil pada siklus berikutnya. 
Tabel 1. Indikator Penilaian

\begin{tabular}{|c|c|c|c|c|}
\hline Lingkup & Indikator & \multicolumn{3}{|c|}{ Kriteria } \\
\cline { 3 - 5 } Perkembangan & Kurang & Cukup & Baik \\
\hline Kesadaran diri & $\begin{array}{c}\text { Memahami } \\
\text { peraturan dan } \\
\text { disiplin }\end{array}$ & $\begin{array}{c}\text { Tidak mau } \\
\text { berbaris saat ingin } \\
\text { masuk kelas }\end{array}$ & $\begin{array}{c}\text { Mau berbaris 2 } \\
\text { sampai 3 kalai } \\
\text { dalam 5 kali } \\
\text { pengamatan }\end{array}$ & $\begin{array}{c}\text { Mau berbaris saat } \\
\text { masuk kelas }\end{array}$ \\
\hline Perilaku prososial & $\begin{array}{c}\text { Menaati } \\
\text { peraturan yang } \\
\text { berlaku }\end{array}$ & $\begin{array}{c}\text { Tidak mau } \\
\text { berbaris saat ingin } \\
\text { masuk kelas }\end{array}$ & $\begin{array}{c}\text { Mau berbaris 2 } \\
\text { sampai 3 kalai } \\
\text { dalam 5 kali } \\
\text { pengamatan }\end{array}$ & $\begin{array}{c}\text { Mau berbaris saat } \\
\text { masuk kelas }\end{array}$ \\
& & & \\
\hline
\end{tabular}

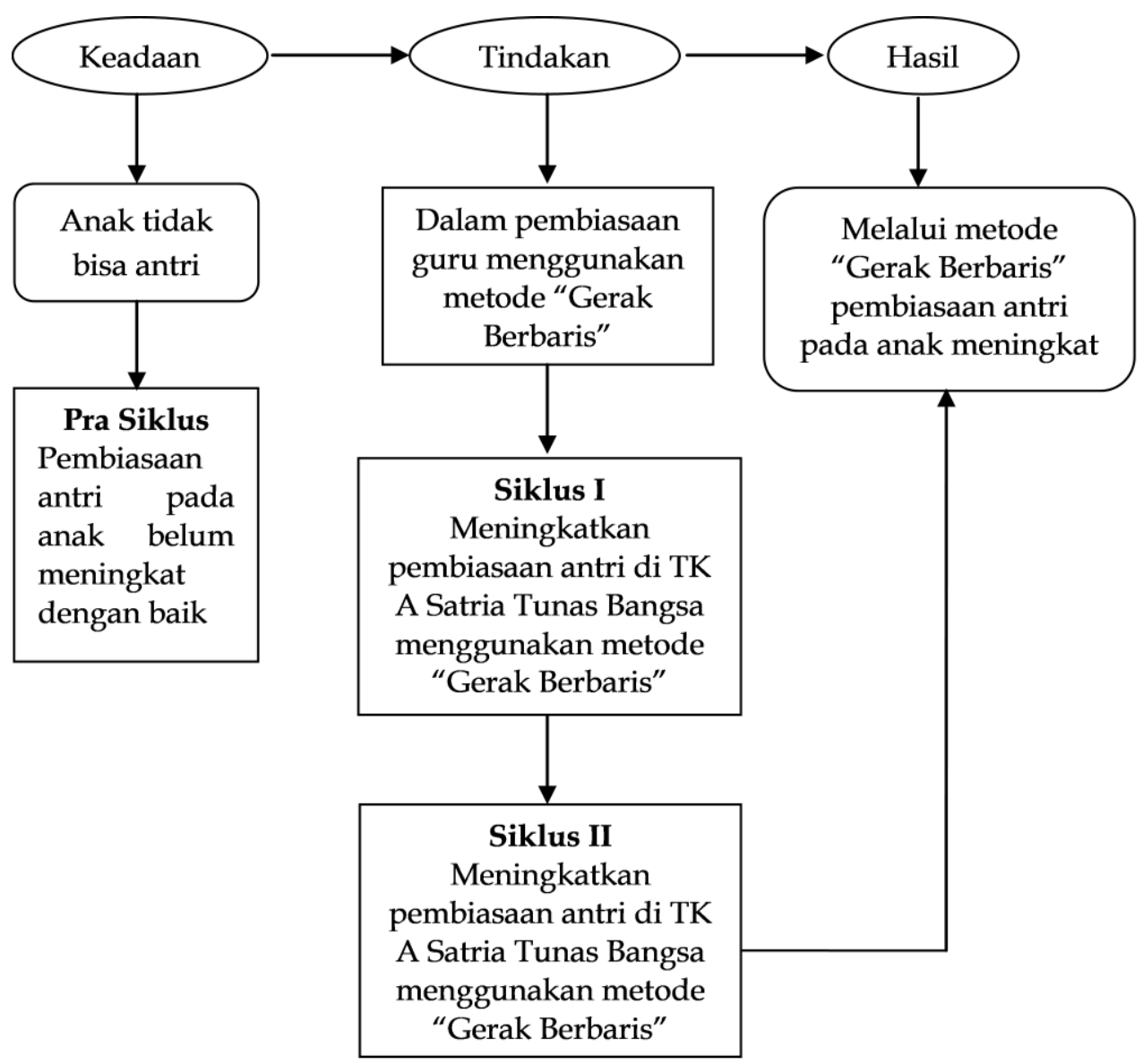

Gambar 2. Alur Pelaksanaan PTK

(Altrichter, Kemmis, Mctaggart, \& Zuber-Skerritt, 2002)

\section{HASIL DAN PEMBAHASAN}

Langkah-langkah penerapan metode "Gerak Berbaris" dalam peningkatan budaya antri yang telah dilakukan peneliti, yaitu: 1) anak diminta untuk berdiri di depan pintu kelas, kemudian guru akan menjelaskan caranya; 2) guru menyapa anak dan sedikit bercakap-cakap tentang apa saja (kegiatan ini bermaksud untuk membangkitkan semangat dan menarik minat dan rasa ingin tahu anak); 3) guru menjelaskan kegiatan yang akan dilakukan; 4) guru meminta anak untuk berbaris, kemudian anak maju satu per satu kemudian anak akan memilih satu gambar yang telah tersedia untuk membuat gerakan bersama guru; 5) setelah itu anak yang sudah selesai melakukan gerakkan langsung masuk kelas dan diikuti anak yang lain. Dalam penerapannya dijelaskan secara rinci pada setiap siklus. 
DOI: 10.31004/obsesi.v5i1.624

\section{Pra-Siklus}

Dari hasil pengamatan pra siklus yang dilakukan selama 5 hari menunjukkan anak yang belum bisa mengantri mencapai $25 \%$ dari hasil perhitungan keseluruhan, sedangkan $75 \%$ anak lainnya sudah mampu menunjukkan kebiasaan mengantri. Saat anak mengantri untuk masuk kelas, anak masih belum bisa antri dan beberapa dari mereka suka mendorong temannya. Pengamatan pada anak saat mencuci tangan menunjukkan 25\% anak belum menaati peraturan yang berlaku saat. Mereka saling mendorong sehingga menyebabkan teman lainnya menangis. Sedangkan $75 \%$ anak lainnya sudah mampu menunjukkan kebiasaan menaati peraturan saat mencuci tangan.

Sesuai dengan hasil pengamatan, anak-anak masih belum terbiasa untuk mengantri. Beberapa dari mereka tidak bisa menunggu giliran dan selalu ingin mendahului temannya. Peneliti melakukan pengamatan pada saat masuk kelas dan saat mencuci tangan. Untuk melakukan penelitian pada tahap selanjutnya menggunakan metode yang telah disediakan peneliti, peneliti telah berdiskusi dengan guru kelas TK A untuk meningkatkan budaya antri menggunakan metode "gerak berbaris" dan peneliti sepakat untuk melaksanakan penelitian tindakan kelas pada siklus I pada tanggal 30 Oktober 2019.

\section{Tindakan Siklus 1}

Dari kriteria mengantri saat masuk kelas mendapatkan hasil pada saat berbaris $27 \%$ anak belum bisa mendengarkan arahan, masih berpindah-pindah tempat dan saling mendorong dan untuk kriteria antri saat mencuci tangan mendapatkan hasil. Dari hasil data (lihat Gambar 2), peningkatan persentase pencapaian anak dalam memahami peraturan disiplin diperoleh sebanyak $73 \%$ dari 20 anak yang diamati selama 3 hari. Pada kriteria menaati peraturan mencuci tangan, $81 \%$ anak sudah mampu mengikuti dengan baik. Terjadi peningkatan sebesar $6 \%$ dari pengamatan saat refleksi awal. Sedangkan $19 \%$ belum mampu menaati peraturan mencuci tangan dikarenakan masih ada anak yang menyerobot dalam barisannya.

Dari tindakan-tindakan yang diberikan pada Siklus I terlihat anak belum sepenuhnya mampu membiasakan diri dalam mengantri. Dalam penerapan gerak berbaris sesuai warna anak-anak diberikan kesempatan untuk mengamati bagaimana guru dan teman-teman yang lain melakukan, mengeksplorasi dan berpikir akan kegiatan yang dilakukan bersama kemudian membiasakan untuk melakukannya melalui learning by doing (Suyanto, 2015). Seperti yang disampaikan oleh para ahli, sebagian besar perilaku manusia dipelajari, dibentuk, dan ditentukan oleh kejadian-kejadian dalam lingkungannya, terutama reward, hukuman, dan peniruan (modeling) (Dewi, Suarni, \& Magta, 2016; Susanti, Siswati, \& Astuti, 2013). Anak-anak pada Siklus I masih membutuhkan banyak tuntunan untuk menirukan dan mengulangi gerak berbaris berulang-ulang. Di sinilah peran guru sebagai role model sangat diperlukan (Redana, 2019).

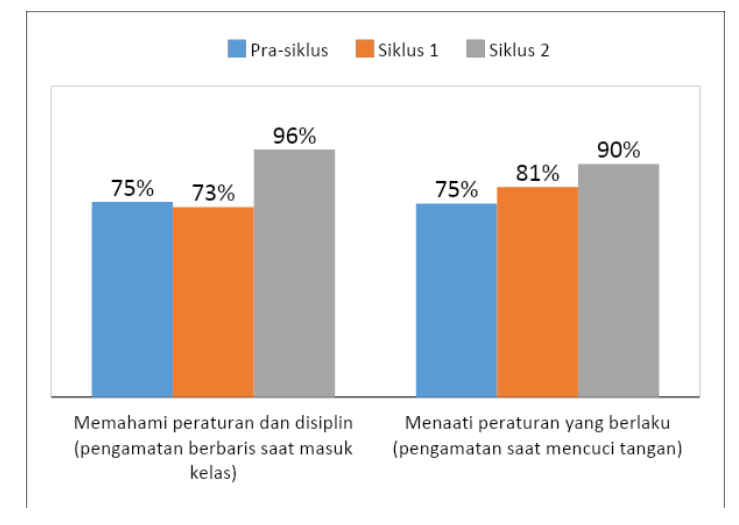

Gambar 2. Persentase Pencapaian Setiap Siklus 
Sebanyak $19 \%$ anak pada Siklus I masih kesulitan menaati peraturan mencuci tangan. Hal ini ditunjukkan dengan perilaku seperti menyerobot dalam barisan. Tidak dipungkiri, dalam masa perkembangannya anak masih berpusat pada aku, yang artinya anak usia dini pada umumnya hanya memahami sesuatu dari sudut pandangnya sendiri, bukan sudut pandang orang lain (Nurmalitasari, 2015). Hal inilah yang perlu menjadi perhatian guru karena merugikan bagi penyesuaian diri dan sosialnya jika terus berlanjut pada tahapan selanjutnya. Jean Piaget memasukkan karakter tersebut pada tahapan kognitif preoperational pada usia 2-7 tahun (Cahyaningrum, Sudaryanti, \& Purwanto, 2017; Suyanto, 2015; Wahyuningsih, 2014).

Membangun budaya antri membutuhkan proses berpikir (Harun, 2017) yang mana mendukung metakognisi anak sangat dibutuhkan yakni membuat anak mampu mengontrol emosinya dengan memilih aktivitas yang menyenangkan dalam mengantri melalui gerakangerakan yang mudah diikuti yang juga selaras dengan kontrol motoriknya. Kontrol kognitif juga diperlukan anak untuk mendukung kinerja otaknya menerima makna dari budaya antri itu sendiri sebagai sebuah kesepakatan (Fitri, 2017). Hal ini memerlukan latihan dan proses modeling berulang kali dari guru kepada anak.

Dari data dan bahasan tersebut dapat disimpulkan bahwa belum adanya pencapaian yang diinginkan oleh peneliti bahkan terjadi penurunan pencapaian $2 \%$ dari hasil pengamatan pada pra-siklus sebagai refleksi. Hal ini dikarenakan masih ada anak yang belum bisa mendengarkan arahan, masih suka berpindah tempat dan sering mendorong teman yang lain. Dari hasil analisis tersebut, peneliti merasa perlu melakukan tindakan lanjutan. Hal ini berarti, peneliti perlu melakukan penelitian di tahap selanjutnya yaitu penelitian pada siklus II.

\section{Tindakan Siklus II}

Dari kriteria mengantri saat masuk kelas mendapatkan hasil pada saat berbaris sebanyak $4 \%$ anak belum bisa mendengarkan arahan, masih berpindah-pindah tempat dan saling mendorong dan untuk kriteria antri saat mencuci tangan mendapatkan hasil. Dari hasil data (lihat Gambar 2), peningkatan yang cukup signifikan pada persentase pencapaian anak dalam memahami peraturan disiplin diperoleh sebanyak 96\% dari 20 anak yang diamati selama 3 hari. Dari data tersebut dapat disimpulkan bahwa sudah adanya pencapaian yang diinginkan oleh peneliti bahkan terjadi peningkatan pesat pencapaian sebesar 23\% dibandingkan hasil pengamatan pada Siklus I.

Terjadinya peningkatan dikarenakan metode yang digunakan yaitu "berbaris sesuai warna" efektif sehingga anak mampu menaati aturan yang diberikan. Yang menunjukkan bahwa anak sudah mampu memahami peraturan berbaris terlihat ketika anak tidak menyerobot lagi dalam barisannya dan mau menunggu giliran. Terjadi peningkatan juga pada kriteria menaati peraturan yang mana sebanyak $90 \%$ anak dapat mengikuti aturan mencuci tangan. Kenaikan persentase sebesar 9\% dari pencapaian sebelumnya pada Siklus I.

Seperti yang diuraikan pada Siklus I, pembiasaan merupakan bagian penting dalam tahapan penalaran prakonvensional dimana anak mula-mula mengembangkan keterampilan hidupnya yang lebih banyak bergantung pada faktor eksternal (Manan, 2017). Dari adanya pembiasan ini internalisasi nilai moral yang di ajarkan akan dapat diwujudkan dalam diri anak. Dari adanya pembiasan tersebut perilaku moral yang di ajarkan akan menjadi suatu kebiasaan yang selanjutnya akan membentuk suatu watak atau tabiat anak (Surur, 2010).

Selain itu, yang menjadi bagian penting dari penerapan pembiasaan kebiasaaan mengantri adalah metode yang menarik dalam pembiasaan sangat mempengaruhi minat anak untuk belajar. Gerak berbaris berdasarkan warna menarik minat anak secara bertahap untuk belajar membiasakan diri dalam mengantri. Kegiatan pembelajaran yang menarik, efektif, menyenangkan akan bermakna bagi anak (Rohmawati, 2015).

Seperti yang kita ketahui anak usia prasekolah umumnya lebih menyukai warna dari pada bentuk (color dominance) dan warna dapat digunakan sebagai dasar stimuli 
DOI: 10.31004/obsesi.v5i1.624

(Sriti, 2004). Hal ini terlihat dari bagaimana antusias anak-anak sejak Siklus I dan terus meningkat pada Siklus II. Anak-anak tampak mengekspresikan diri dalam menerapkan kebiasaanya mengantri sebelum memulai pembelajaran, tanpa adanya paksaan ataupun pengendalian dari guru kelas, namun di saat yang bersamaan tetap mewujudkan prinsip belajar dan bermain menyenangkan hingga kemampuan prososialnya berkembang (Simbolon, 2014).

\section{SIMPULAN}

Kemampuan mengantri pada anak menjadi hal yang penting dalam perkembangan sosial-emosional, namun namun pengamatan pendahuluan yang dilakukan oleh peneliti di TK Satria Tunas Bangsa menunjukkan bahwa masih banyak anak yang belum mampu mengantri. Melalui penerapan metode "Berbaris sesuai warna" terlihat bahwa metodi ini dapat meningkatkan budaya antri AUD yang mana ditujukan dari adanya peningkatan ratarata persentase peningkatan antri dari pra siklus sampai siklus II. Hal ini dikarenakan, metode "berbaris sesuai warna" adalah salah satu strategi pembelajaran yang sesuai dengan prinsip pembelajaran pada anak usia dini, yaitu bermain sambil belajar. Anak juga dapat meningkatkan budaya antri sambil mengenal warna.

\section{UCAPAN TERIMA KASIH}

Ucapan terima kasih kami sampaikan kepada Kepala Sekolah, para guru dan siswa TK Satria Tunas Bangsa Salatiga yang telah memberikan kesempatan melakukan penelitian di sekolah ini.

\section{DAFTAR PUSTAKA}

Altrichter, H., Kemmis, S., Mctaggart, R., \& Zuber-Skerritt, O. (2002). The concept of action research. The Learning Organization, 9(3), 125-131. https://doi.org/10.1108/09696470210428840

Cahyaningrum, E. S., Sudaryanti, S., \& Purwanto, N. A. (2017). Pengembangan Nilai-Nilai Karakter Anak Usia Dini Melalui Pembiasaan Dan Keteladanan. Jurnal Pendidikan Anak, 6(2), 203-213. https://doi.org/10.21831/jpa.v6i2.17707

Dewi, I. D. K. E., Suarni, N. K., \& Magta, M. (2016). Penerapan Teknik Modeling Untuk Meningkatkan Disiplin Pada Anak Usia 5-6 Tahun. Jurnal Pendidikan Anak Usia Dini Undiksha. https://doi.org/http:/ /dx.doi.org/10.23887/paud.v4i3.8835

Diana, M. (2010). Psikologi Bermain Anak Usia Dini. بيياريهاى داخلى

Fitri, R. (2017). Metakognitif pada Proses Belajar Anak dalam Kajian Neurosains. Jurnal Pendidikan (Teori Dan Praktik). https:// doi.org/10.26740/jp.v2n1.p56-64

Hakim, A. R., \& Kumala, F. N. (2016). Pengembangan Karakter Melalui Kegiatan Outbound. Jurnal Moral Kemasyarakatan, 1(2), 173-182. https:// doi.org/10.21067/JMK.V1I2.1534

Harliana. (2019). Penerapan Yoga dalam Menstimulasi Kemampuan Disiplin Anak Usia Dini. Jurnal Tumbuhkembang : Kajian Teori Dan Pembelajaran PAUD.

Harun, H. (2017). Model Pendidikan Karakter Untuk Membangun Potensi Harmoni Sosial Anak Usia Dini Di Yogyakarta. Jurnal Penelitian Ilmu Pendidikan, 10(1), 53. https://doi.org/10.21831/jpipfip.v10i1.16796

Hodijah, S., Rachmawati, Y., \& Agustin, M. (2019). Upaya Guru Dalam Menanamkan Sifat Sabar Di Ra Persis I Kota Bandung. Edukid, 15(2), 95-102. https://doi.org/10.17509/edukid.v15i2.20604

Manan, S. (2017). Pembinaan Akhlak Mulia Melalui Keteladanan Dan Pembiasaan. Jurnal Pendidikan Agama Islam-Ta'lim.

Mann, L. (1969). Queue Culture: The Waiting Line as a Social System. American Journal of Sociology. https:/ / doi.org/10.1086/224787

McClelland, M. M., Wanless, S. B., \& Lewis, K. W. (2016). Self-Regulation. In Encyclopedia of 
Mental Health: Second Edition. https://doi.org/10.1016/B978-0-12-397045-9.00038-0

McClelland, Megan M., \& Tominey, S. L. (2018). Self-Regulation in Early Childhood. In Stop, Think, Act. https:/ / doi.org/10.4324/9781315798059-1

Mukti, A. (2014). Hakikat Anak Usia Dini. Perkembangan Dan Konsep Dasar Pengembangan Anak Usia Dini.

Musfiroh, T. (2012). Teori dan Konsep Bermain. Musfiroh, T., E Hum, M. (2014). Teori Dan Konsep Bermain.

Nurmalitasari, F. (2015). Perkembangan Sosial Emosi pada Anak Usia Prasekolah. Buletin Psikologi. https:// doi.org/10.22146/bpsi.10567

Redana, I. W. (2019). Meningkatkan Keterampilan Sosial Melalui Penerapan Teknik Modeling Anak Kelompok A di TK Tunas Kartini 1 Culik. Pratama Widya : Jurnal Pendidikan Anak Usia Dini, 4(2), 90-100. https:/ / doi.org/10.25078/PW.V4I2.1165

Rohmawati, A. (2015). Efektivitas Pembelajaran. Jurnal Pendidikan Usia Dini.

Simbolon, N. (2014). Faktor Faktor Yang Mempengaruhi Minat Belajar Peserta Didik. Elementary School Journal Pgsd Fip Unimed. https:// doi.org/https:// doi.org/10.24114/esjpgsd.v1i2.1323

Sriti, M. S. (2004). Peran Warna Interior Terhadap Perkembangan Dan Pendidikan Anak di Taman Kanak-Kanak. Dimensi Interior,

Surur, M. (2010). Problematika Pendidikan Moral di Sekolah dan Upaya Pemecahannya. Jurnal Fikroh.

Susanti, S., Siswati, S., \& Astuti, T. P. (2013). Perilaku Prososial : Studi Kasus Pada Anak Prasekolah. Empati, 2(4), 475-482.

Suyanto, S. (2015). Pendidikan Karakter untuk Anak Usia Dini. Jurnal Pendidikan Anak. https:// doi.org/10.21831/jpa.v1i1.2898

Umayah, U. (2016). Menanamkan Moral Dan Nilai-Nilai Agama Pada Anak Usia Dini Melalui Cerita. Aș -Șibyān: Jurnal Pendidikan Anak Usia Dini.

Wahyuningsih, S. (2014). Pendidikan Anak Usia Dini (PAUD). Media Prestasi Jurnal Pendidikan STKIP PGRI Ngawi.

Zubaida. (2016). Implementasi Pendidikan Karakter Anak Usia Dini. Madaniyah. 